\title{
Mammalian Cell Behavior on Hydrophobic Substrates: Influence of Surface Properties
}

\author{
Michele Ferrari ${ }^{1,2, * \mathbb{D}}$, Francesca Cirisano ${ }^{1} \mathbb{D}$ and M. Carmen Morán ${ }^{2,3, * \mathbb{C}}$ \\ 1 CNR-ICMATE Istituto di Chimica della Materia Condensata e di Tecnologie per l'Energia, via De Marini, 6, \\ 16149 Genova, Italy; francesca.cirisano@ge.icmate.cnr.it \\ 2 Institut de Nanociència i Nanotecnologia-IN²UB, Universitat de Barcelona, Avda. Diagonal, 645, \\ 08028 Barcelona, Spain \\ 3 Departament de Bioquímica i Fisiologia, Secció de Fisiologia-Facultat de Farmàcia i Ciències de \\ l'Alimentació, Universitat de Barcelona, Avda. Joan XXIII s/n, 08028 Barcelona, Spain \\ * Correspondence: michele.ferrari@ge.icmate.cnr.it (M.F.); mcmoranb@ub.edu (M.C.M.)
}

Received: 26 March 2019; Accepted: 7 May 2019; Published: 7 May 2019

\begin{abstract}
The influence of different surface properties holding to a modification of the substrate towards hydrophobic or superhydrophobic behavior was reviewed in this paper. Cell adhesion, their communication, and proliferation can be strongly manipulated, acting on interfacial relationship involving stiffness, surface charge, surface chemistry, roughness, or wettability. All these features can play mutual roles in determining the final properties of biomedical applications ranging from fabrics to cell biology devices. The focus of this work is the mammalian cell viability in contact with moderate to highly water repellent coatings or materials and also in combination with hydrophilic areas for more specific application. Few case studies illustrate a range of examples in which these surface properties and design can be fruitfully matched to the specific aim.
\end{abstract}

Keywords: biological applications; cell adhesion; hydrophobicity; superhydrophobicity; mammalian cells; protein adsorption; surfaces properties; wettability

\section{Introduction}

Cell adhesion between cells and surfaces is a crucial controlling parameter on biological processes ranging from activation, differentiation, migration, proliferation, or purely survival [1]. These adhesive interactions between cells and biomaterials could determine the final applicability of implanted prostheses by regulation of the inflammatory responses and degree of connection to immediate tissues. Nowadays, it is widely recognized that the control of biological adhesion is controlled by specific interactions between cell surface receptors and their ligands, although the influence of nonspecific forces must not be forgotten [2].

Changes in cell adhesion have been detected in a wide range of diseases such as arthritis $[3,4]$, cancer [5-7], osteoporosis [8,9], and atherosclerosis [10,11]. In general, cell adhesiveness is reduced in human cancers, where the diminished intercellular adhesiveness allows cancer cells to migrate, resulting in the loss of the histological structure, which is the morphological distinctive of malignant tumors [7]. Tumor cells are characterized by changes in adhesion to extracellular matrix (ECM), which may be related to their invasive and metastatic potential. Cell-matrix as well as cell-cell interactions have been reported to be cell type- and oncogene-specific [12-14].

When cells adhere to the surface of a material, a sequence of physicochemical reactions between the cells and the material interface occurs. The first event after the biomaterial is implanted into an organism is the protein adsorption to its surface, which mediates the cell adhesion and offers signals to the cell through the cell adhesion receptors, mainly of the integrin type [15]. Cells can adhere on the 
surfaces and release active compounds, which would mediate deposition of the extra-cellular matrix, differentiation, and even cell proliferation.

Interfacial interactions between cell/tissue and surfaces correlate quite well with many important phenomena in biological systems and have been considered for the development of several artificial biomaterials and applications [15-18]. To fabricate scaffolds and implants for tissue engineering and regenerative medicine, biomimetic materials promoting a favorable response from cells and tissues are required. Most biomedical devices, however, because of the contact with blood or tissues, require those bioinert polymers suppressing nonspecific adhesions that could induce trombosis and immunological responses [19-24].

The biocompatibility of a material refers to its capability to provide appropriate support to cellular activity, including the stimulation of molecular and mechanical processes, which would optimize tissue regeneration, without producing any undesirable response in the eventual host, either at local or systemic level [25-27]. When the in vitro biocompatibility of a biomaterial is determined, it depends mainly on its own surface properties, such as stiffness, surface charge, chemical functionalities, roughness, and wettability, and on the cell interactions with the scaffold's degradation products [28]. Besides this, the culture medium and conditions, as well as the type of cell, are important parameters that also modulate the behaviour of cells. Figure 1 summarizes the main surface properties that may affect cell behavior in terms of the adhesion, morphology, metabolism, and proliferation, among others.
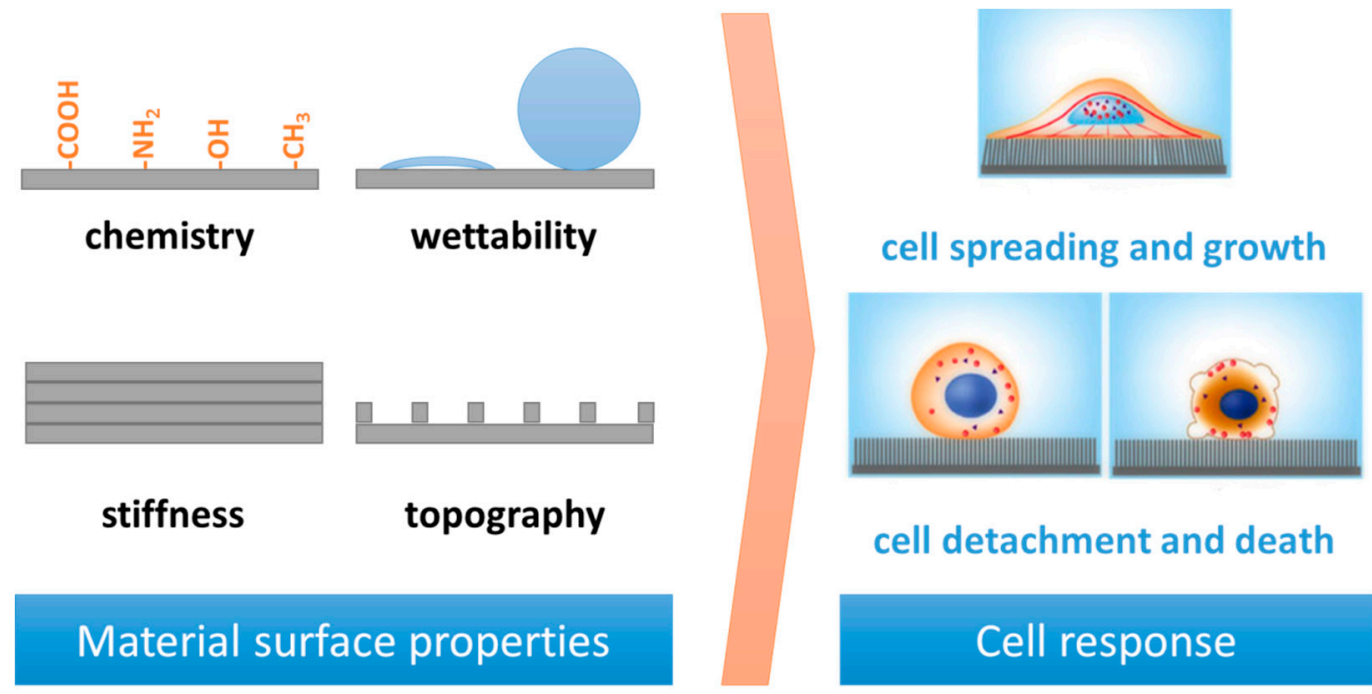

Figure 1. Schematic representation of the main surface properties and their direct effect on cell behavior.

Surfaces prepared with particular characteristics can control adhesion and proliferation of cells on substrate surfaces. Different techniques have been applied, aimed at introducing chemical groups addressing the behavior to hydrophilicity or hydrophobicity, as well as physically modifying the surface in terms of roughness, surface energy, or morphology. Plasma treatment is among one of the most popular and reliable methods for an appropriate surface modification [29-32].

As the prediction of a precise mechanism of interaction of a surface in biological environment is complicated by the composition of body fluids (water, various proteins), as well as by cells' synergistic interaction $[33,34]$, surface properties in terms of surface wettability with respect to their hydrophobicity or hydrophilicity have an important role in influencing the biological response of a biomaterial [35]. In this work, we review the available literature about a few physico-chemical and mechanical properties of a surface and dynamic processes at the interfaces significantly affecting the behavior of mammalian cells, together with case studies focused on highly repellent substrates. 


\section{Surface Properties and Cell Response}

\subsection{Surface Stiffness}

The modulation of cell attachment, differentiation, and proliferation has been shown to be influenced by the substrate rigidity measured by material surface stiffness [36-38]. Mechanical stimuli also induce responses in cells like migration and alterations in the adhesiveness between cells and cell-matrix; nevertheless, the role of the environment in comparison with chemical regulations at ECM level is still not well debated.

Integrins are used by cells to sense stiffness, creating either structure to attach to the ECM and traction forces by actomyosin contraction, modifying their environment [39]. Cell behaviour is influenced by mechanical and chemical signals produced by the extracellular environment as a mediator of cell health, and it has been observed how cellular dysfunction and disease progression depend on altered mechanical properties of tissues. Material design with tailored surface properties attempts to understand the pathway through the mechanical properties of the ECM contributing to cell responses and tissue formation mainly associated with disease of aberrant mechanosensing states.

A limited number of studies have yielded exciting results on how the elastic modulus of substrates strongly influences cell spreading. The mechanism between cell-ECM is then dependent on softness and stiffness, with great correlation with cell adhesion response. Atomic force microscopy (AFM) with biological samples had a great impact in allowing the assessment of mechanical measurement at the local micro-nanoscopic level. Surface imaging and detection of interaction forces among the various functionalities of the technique allow the assessment of quantitative parameters characteristic changes occurring in various diseases. An important example could be the use of AFM in the characterization of cancer progression through biophysical fingerprints as biomarkers of the disease. The great contribution of AFM studies in this case has been on cellular deformability measurements and quantification of the interaction forces at the single-molecule and single-cell levels, comparing AFM-derived properties of reference and cancerous cells using all functionalities. The implementation of AFM as routine cancer tracking and diagnosis is still hard to forecast because of many practical issues yet to be overcome, even if such a microscope technique has shown broad evidence of applicability in cell altered and pathological states. One of the main limitations to a large scale use and practical applicability of AFM in clinical practice is the relativeness of the direct comparison of Young's modulus between various laboratories [40]. With the large database showing an increased deformability of single cancerous cells, tissue sections, and biopsies, the better understanding of cancer-related processes and mechanisms will open the highway for the future development of clinical quantitative assays.

Biologically inert, polydimethylsiloxane (PDMS) is a polymer frequently used as a cell culture substrate because of its tunable elastic properties. The effect of PDMS substrate stiffness on the cell adhesive and proliferative properties of normal and cancerous cell lines has been recently reported [41,42]. By means of UV irradiation, PDMS substrates with stiffness tuned monotonically from 0.24 MPa to 1.67 MPa [41] or between $0.75 \mathrm{MPa}$ and 2.92 MPa [42]. It is noteworthy that the surface properties of PDMS substrates, in terms of topography, hydrophobicity, chemical composition, and protein absorption, are not modified by the UV irradiation of tuning substrate stiffness. By verifying that the surface properties' results, like topography, hydrophobicity, chemical composition, and protein adsorption, on cell behavior demonstrated that it only occurs as a result of substrate elasticity. In general, softer PDMS substrate was demonstrated to be more compatible with the adhesion and growth of cells, while cells responded poorer to stiffer PDMS substrates.

Even if plasma is usually used to make hydrophobic PDMS surfaces more biocompatible, the surface mechanical properties' result was altered by such treatments. Recently, it has been evidenced how plasma treatment on PDMS resulted in consistent surface stiffening at depths up to 1 micron, while this parameter exponentially decreases at depths of $1 \mathrm{~mm}$ [43]. Finite element (FE) analysis allowed an interpretation of AFM indentation results determining the substrate material properties with the aim of separating the influence of the underlying substrate on the surface. From such an analysis, a two-layer 
material model composed of one thin and stiff plasma-oxidized layer on a thicker layer of more elastic bulk polymer could fit the experimental data. This study clearly described a novel approach for characterizing the effect of the biopolymer surface modifications on cell-biomaterial mechanics

\subsection{Surface Charge and Chemical Functionalities}

It has long been known by electrophoretic measurements that mammalian cells bear a net negative charge [44]. Consequently, the interaction between cells and negative surfaces can be used to minimize cell adhesion by electrostatic repulsion. The results using low ionic strength medium, such as physiological media [45] and grafted polymer brushes on substrates [46], have demonstrated that cell-surface adhesion could be prevented. When the protein adsorption on negatively charged surfaces is considered, the degree of adsorption would depend on the ionic strength of the nearby solution [47], mainly mediated by the release of the corresponding counterion of the polymers into the solution.

The effect of surface charge has been extensively analyzed in the cell attachment mechanism. The amount of positive charges on the surfaces can strongly influence cell behavior. Several studies have demonstrated how cell adhesion and proliferation can be modulated by surface charge density. Figure 2 demonstrates how, as the degree of charge density of hydrogels based on 2-hydroxyethyl methacrylate (HEMA) and 2-methacryloxyethyl trimethyl ammonium chloride (MAETAC) copolymer increased, cell adhesion and proliferation are favored [48].
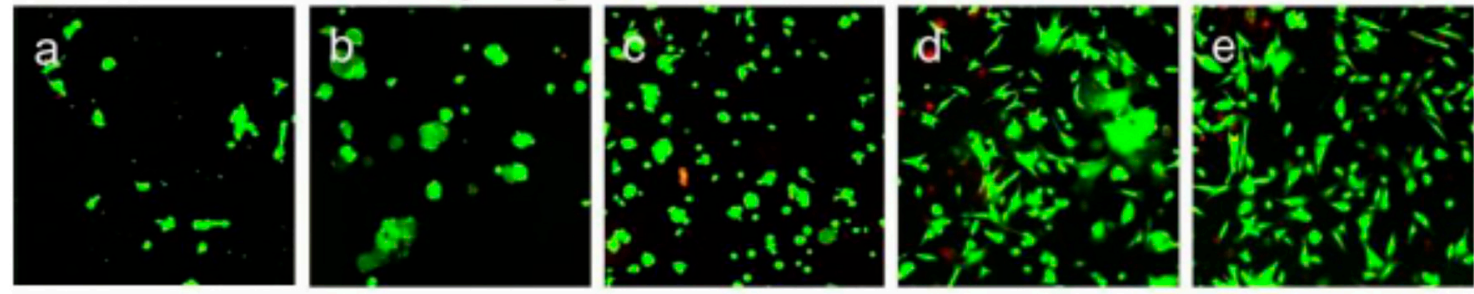

Figure 2. Fluorescence microscopy images showing changes on chondrocyte adhesiveness on hydrogels with different concentrations of MAETAC ranging from $0 \%(\mathbf{a}), 5 \%(\mathbf{b}), 10 \%$ (c), $20 \%$ (d), and 30\% (e). Reprinted from reference [48] with permission from Elsevier.

An improved biocompatibility and cell differentiation on the substrate surfaces can be achieved using both positive negative ions [49]. For instance, the characterization of osteoblasts and fibroblasts behavior on 2-hydroxyethyl methacrylate hydrogels modified with positive charges demonstrated higher cell attachment and spreading compared with negative or neutral charges [50]. The attachment of neuronal cells has been also improved on positively charged coating materials, such as polylysine. Likewise, the functionalization with negative charges of oligo(poly(ethylene glycol) fumarate) hydrogels increased the extent of chondrocyte differentiation and expression of collagen and glycosaminoglycan, in comparison with that observed on neutral or positively charged hydrogel scaffolds [51]. Similar behavior has been observed on the neuronal growth [52].

The introduction of chemical functionalities on surfaces has been also used to modify cell behavior. Studies on polyethylene (PE) surfaces with differently chargeable functional groups $\left(-\mathrm{COOH},-\mathrm{CH}_{2} \mathrm{OH}\right.$, $-\mathrm{CONH}_{2}$, and $-\mathrm{CH}_{2} \mathrm{NH}_{2}$ groups) demonstrated that the best cell adhesion, growth, and spreading rate are performed on polar and positively charged surfaces (amine group), whereas more limited growth was reported on the negatively charged surface (carboxylic acid group) [53]. Although the surfaces modified with neutral amide and hydroxyl groups showed a similar number of cell attachments, cells on the hydroxyl group-modified surfaces spread much more than in those in the presence of amide groups.

Control of cell adhesion can be achieved by modulation of protein adsorption via integrin binding on negative modified surfaces [54]. Reports in the literature demonstrated the control of cell adhesion of MC3T3 osteoblasts on surfaces functionalized with ionizable groups by modulation of fibronectin adsorption and integrin binding, following the trend $\mathrm{OH}>\mathrm{COOH}=\mathrm{NH}_{2}>\mathrm{CH}_{3}$ [55]. Grafted 
surfaces with amine and hydroxyl groups confirmed alkaline phosphatase enzymatic activity and matrix mineralization, and up-regulated osteoblast-specific gene expression in comparison with that observed with surfaces functionalized with alkyl and carboxyl groups [56].

Surface charge, along with wettability properties, has been extensively reported in the literature as two physical issues governing protein adsorption and cell adhesion. Although the comparison between these two driving forces in terms of their independent and cooperative effects on cell adhesion is rarely explored, a recent work has developed a protocol featuring two-dimensional control over both surface charge and wettability influence [57]. This approach allows the control of both the assembly of the polyion charge density in the layer-by-layer (LbL) and the polyion side-chain chemical structures. Surface isoelectric points ranging from 5 to 9 and water contact angles from $35^{\circ}$ to $70^{\circ}$ on the 2D property matrix were compared. The relationship between the two surface parameters influences both protein (bovine serum albumin, lysozyme) adsorption and 3T3 fibroblast cell adhesion. The highest cell adhesion was found by the combined effects of positive charge and hydrophilicity, while a most limited cell adhesion was promoted by negative charge and hydrophobicity.

\subsection{Surface Roughness}

Material surface roughness (or topography) is another important parameter influencing both cell behavior and adhesion. It has been established that roughness modulates the cell response in contact with the implanted material. Surface roughness strongly influences cellular morphology, proliferation, and phenotype expression in vitro as well as in vivo.

Topographical features of the substrates at micro or nano scale like fibres, grooves, ridges, steps, pores, wells, and nodes have been studied as a function of the cell response caused by its interaction with different geometries and chemistry. Surface roughness of the material surface can be divided into nanoroughness (less than $100 \mathrm{~nm})$, microroughness (100 nm-100 $\mu \mathrm{m})$, and macroroughness $(100 \mu \mathrm{m}-1 \mathrm{~mm})$, showing their own influence [58].

Studies in the literature demonstrated that the effect of roughness is different depending on the cell size. The macroscopic effect of the surface roughness could be considered for larger cells, such as osteoblasts and neurons [59]. Polycarbonate (PC) membrane surfaces with micropore size ranging between $200 \mathrm{~nm}$ and $8.0 \mu \mathrm{m}$ were used to evaluate the behavior of MG63 osteoblast-like cells [60]. As shown in Figure 3, PC membranes with microspores with higher sizes inhibited the cell adhesion. In addition, the increase of micropore size promoted cell differentiation as well as higher expression of osteocalcin and ALP activity in isolated cells. The effect of roughness on neuronal cell responses in surfaces confirmed that the nanoscale rough surfaces (up to tens of $\mathrm{nm}$ ) promotes the increase of both the length of the axon and the number of branches of the neuritis. For microscale rough membranes (up to hundreds of $\mathrm{nm}$ ), round-shaped soma with a limited number of branches confirmed the presence of less developed neurons [61].

The surface roughness at nanometer scale of a biomaterial surface has been employed to improve cell adhesion and growth for smaller cells, such as human vein endothelial cells [62]. Human mammary epithelial cells (hTERT-HME1) were cultured either in plain and dendrimer-immobilized surfaces with different surface roughness. In the naked dendrimer surface $(4.0 \mathrm{~nm})$, cells were rich in F-actin filaments, compared with the morphology of cells on a plain surface [63]. The increase of surface roughness for values higher than $4.0 \mathrm{~nm}$ promoted the presence of round-shapes cells as a consequence of the inhibition on cell stretching. A similar behavior has been reported on culturing fibroblasts [64]. The rate of proliferation of MC3T3-E1 osteoblastic cells seems to be much higher on smooth regions $(0.55 \mathrm{~nm})$ than on the rough regions $(13 \mathrm{~nm})$ of the films [65].

The adhesion and viability of fibroblast cells on highly rough three-dimensional (3D) silicon (Si) surfaces have been studied in the work of [66]. The aim was to investigate culture surfaces with gradient roughness ratios and wettabilities produced by femtosecond (fs) laser. Structuring Si wafers resulted in controlled dual-scale roughness composed by conical spikes at both the micro- and the nano-scale. By changing the laser pulse fluency, different roughness levels could be obtained, 
influencing surface energy and controlling wettability by covering the structures with suitable coatings, acting on the surface chemistry without affecting morphology. Lower roughness ratios indicated better fibroblast cell adhesion, non-monotonically dependent on surface energy, but independent from surface wettability and chemistry. The role of size and shape of surface topography on cell attachment is well underlined, showing how laser structured scaffolds, at controlled roughness ratio and surface chemistry, could be a promising in vivo method to define 3D cell-biomaterials interactions. The main original finding emerging from this paper is the synergistic role of the roughness degree and surface chemistry defining wettability or surface energy features of the substrate. These two parameters are in turn responsible for switching properties from cell-phobic to cell-philic behavior or from super-hydrophobic to super-hydrophilic with a well-defined transition point in the wettability.
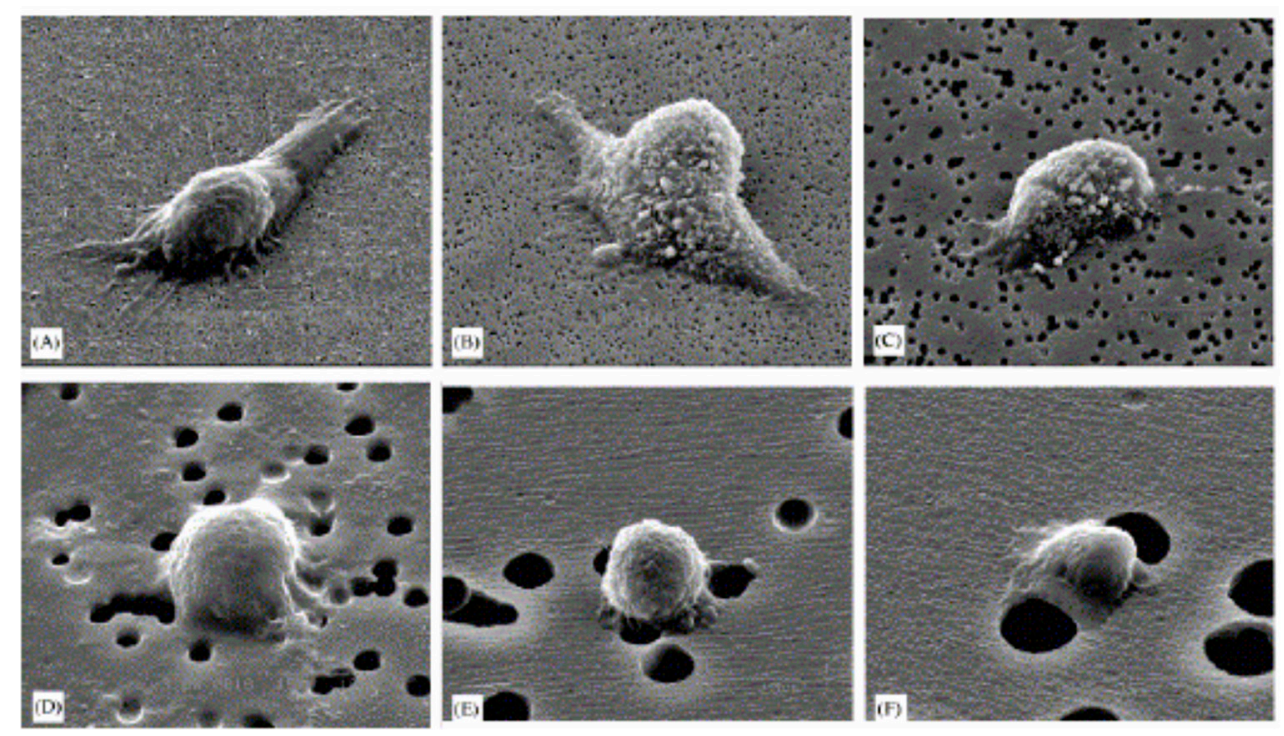

Figure 3. Scanning elelctron microscopy images of MG63 cells attached on the polycarbonate (PC) membrane surfaces with micropore sizes ranging from 0.2 (A), 0.4 (B) 1 (C), 3 (D), 5 (E), and $8 \mathrm{~mm}(\mathbf{F})$. Reprinted from reference [60] with permission from Elsevier.

The effect of both chemical composition and topography on the surface have been evidenced by the introduction of hydrophilic Pluronic copolymer onto the polyurethane (PU) surface, with a lotus leaf-like topography [67]. The obtained surfaces were demonstrated to be inert to both protein adsorption and L929 fibroblasts cells adhesion. Recent studies have pointed out the influence of wettability instead of polymer topography on the inhibition of cell adhesion on flat and rough surfaces.

\section{Dynamic Processes at the Interfaces}

Surface tension related phenomena like wetting and wettability are dynamic interfacial processes and critical factors for the cell behavior. For instance, biological relevant properties like proteins' conformation are strongly affected by interfacial adsorption and adsorbed material, with an indirect influence on the interactions between cell and substrate [68-71]. Research based on polydimethylsiloxane (PDMS) substrate confirmed that this is an easily tunable material for cell-substrate interactions studies because of its mechanical properties influencing surface chemistry and cell response [72]. Changes in formulation resulted in significant changes in elastic modulus without changing the wettability, which shows an inverse behavior with stiffness after polyelectrolytes' adsorption. Under these different composition conditions, cell attachment and spreading are governed by surface properties at early stages, while cell growth depends on mechanical properties at longer times.

Under another perspective, applications requiring a particular cell response on a specific substrate can benefit of a surface modification, inducing selective adhesion of cells through a competitive adsorption [28]. In recent years, more and more attention has been paid to extreme wettability states, 
which can address the ability of any solid surface to be wetted when in contact with a liquid to discriminate biological environments. Water contact angle (WCA), although not exclusively, is still the key experimental tool to assess such particular characteristics; thus, according to the value of the angle, a surface is considered hydrophobic when it is between $150^{\circ}$ and $90^{\circ}$, but superhydrophobic when WCA is higher than $150^{\circ}$, hydrophilic when it is between $90^{\circ}$ and $10^{\circ}$, and superhydrophilic when it is lower than $10^{\circ}$.

With the WCA being the angle subtended by the droplet of water and the surface, the wettability is derived from an inverse measure or interpretation of the WCA and, in addition, its measurement requires different experimental and theoretical tools when approaching heterogeneous substrates or non-ideal materials. Historically, some surface models have been proposed to predict and explain the way surface interacts with water [73]. For instance, the Young model [74] is applicable for smooth and chemically homogeneous surfaces, while those who mostly contributed to the interpretation of such extreme wettability states like artificial superhydrophobic surfaces are the Wenzel [75] and the Cassie-Baxter models [76] (Figure 4). Both starting from the observation of animal water repellent surfaces, Wenzel considers that the droplet can make full contact with the surface, and, by contrast, Cassie and Baxter better understood the superhydrophobicity, taking into account the air entrapped under the droplet between the surface projections.

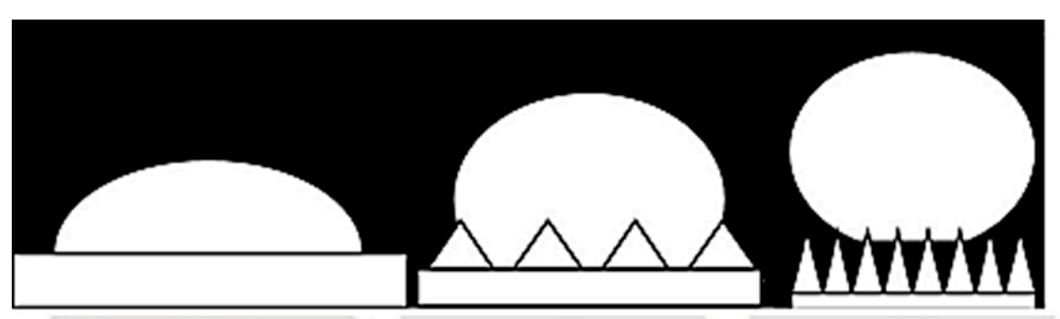

(a)

(b)

(c)

Figure 4. Representation of the Young (a), Wenzel (b) and Cassie-Baxter (c) models showing the main differences in terms of surface and interactions with the droplet.

Despite the fact that the Cassie-Baxter state can be considered stable, few relevant conditions can recover the Wenzel state treating the surface mechanically with vibration, acoustic pressure, hydraulic pressure, or removing the air layer by changing the surface energy [77-79]. Also, the presence of proteins and biological surfactants create specific environmental conditions that are relevant when dealing with biomedical applications; in fact, the growth of biofilm precursor of "bio-fouling" is an assessed reason affecting the durability of air plastron entrapped in the surface grooves [80-83]. Nevertheless, the permanent existence of a bubble significantly delays the colonization by microorganisms and, in general, higher apparent contact angles still underline an increased stability of a superhydrophobic surface $[84,85]$.

Wettability can be considered as the main controlling parameter to explain the different cell behavior on smooth and rough surfaces compared with the influence of both polymer chemistry and topography of superhydrophobic surfaces on cell behavior [35]. Cells' interaction with the substrate material is controlled by the presence of entrapped air and cellular attachment to a substrate is required for many in vitro and in vivo applications. Roughness and curvature of a superhydrophobic surface affect cell spreading and proliferation, reducing both cellular activities with materials possessing greater contact angles. The results obtained through cell adhesion, viability, and proliferation studies evidenced the decreasing of affinity of MC3T3-E1 cell line and primary $\mathrm{BCH}$ cells induced by roughness due to the phase separation. Accordingly, the superhydrophobic surfaces promoted cell adhesion, but inhibited their proliferation; in fact, despite that cells attached and proliferated better on smooth surfaces, on the other hand, on rough superhydrophobic surfaces, cells were still metabolically active and able to adhere and survive, while proliferation was generally inhibited on rough polystyrene (PS) and poly(L-lactic acid) (PLLA). 
Additionally, the control of protein adsorption, either through the inhibition of entire or selective adsorption to the biomaterial surface, has important implications for many applications discussed in this review, from cellular interactions to diagnostic and drug delivery platforms. Hydrophobic surfaces have been traditionally considered as suppressors of protein adsorption, with their hydrophobic residues within the folded three-dimensional structure. Recently, this approach has been clarified, showing that proteins adsorb to hydrophobic materials by direct interactions of hydrophobic patches on the protein surface, as well as through denaturation processes, allowing the protein to bind to the material surface, exposing the internal hydrophobic residues.

On the other hand, minimal protein denaturation or unfolding is generally found because of the interaction of the hydrophilic moieties on the proteins surface with a hydrophilic biomaterial surface. Nevertheless, the development of a biomaterial or a biomedical application has to take into account protein adsorption phenomena of a large number of macromolecules in vivo with different structural and physico-chemical properties [86-88]. Recently, mixed superhydrophobic-superhydrophilic patterned surfaces could exploit such opposite properties to precisely organize and cultivate closely adjacent arrays of different cell lines, for diagnostics and cell signaling studies or tissue engineering [89].

\section{Case Studies}

The development of biomedical applications seeks biomaterials with a suitable anti-adhesive effect on cells or tissues in the body and, at the same time, with health and body protection from traumas or foreign bodies, with tissue adhesion barriers physically isolating wounds or devices [90]. In the following section, a few selected applications describe the behaviour of mammalian cells on surfaces coated by low wettable systems, ranging from common polymers to more complicate combinations with opposite behaviours.

a. The influence of the composition of poly(dimethylsiloxane) (PDMS) was investigated, studying the attachment and growth properties of several different types of mammalian cells: primary human umbilical artery endothelial cells (HUAECs), transformed 3T3 fibroblasts (3T3s), transformed osteoblast-like cells (MC3T3-E1), and transformed epithelial cells (HeLa). Cells' growth has been studied on PDMS at different ratios of curing agent, that is, 10:1 v/v (normal PDMS, PDMSN), 10:3 v/v (PDMSCA), and 10:0.5 v/v (PDMSB), as well as on extracted PDMS (normal PDMS with reduced quantities of low molecular-weight oligomers, PDMSN, EX), normal PDMS extracted and then oxidized (PDMSN, EX, OX). Before the cell attachment step, all surfaces were exposed to a solution of fibronectin, being fibronectin-coated PDMS as suitable substrate for culturing mammalian cells [91]. The cell type appeared to be the most influencing factor of cells compatibility on some surfaces; 3T3 fibroblasts and MC3T3-E1 cells showed detachment from PDMSN, EX, OX, while HUAECs and HeLa cells detached from the PDMSCA surface. For most of the cell types on PDMSN, PDMSN, EX, and PDMSB, cell growth was comparable to standard tissue culture-treated polystyrene (TCPS). Despite Young's moduli range, the growth rate was found to be similar for all cells on PDMS substrates and then independent on substrate stiffness.

b. Bioinspired superhydrophobic surfaces were prepared based on intrinsically hydrophobic PDMS by roughening a structure using surface aggregates of nanoparticles [92]. The wettability data resulted in a direct dependence of WCA with the increasing of concentration of hydrophobic $\mathrm{TiO}_{2}$. A correlation between surface properties and cell-surface interactions supported the cell adhesion studies carried out in this work. Only the superhydrophobic sample showed a cell-repellent behavior, with a decreasing of cell viability up to $80 \%$ compared with the pure PDMS film. The surface energy was shown to play a key role in the cell-repellent behavior of the superhydrophobic sample, because of similarities in the roughness profiles of the two samples. This work underlines how surface wettability, roughness, and chemistry are parameters of optimization for developing biomaterial surfaces with controlled cell adhesion behavior.

c. The effect of enhancing the water repellence of the substrate was evaluated by determining the adhesion and spreading of human fibroblasts on untreated FEP-Teflon (hydrophobized), and 
was also compared with TCPS [93]. Ion etched Superhydrophobic FEP-Teflon was prepared and followed by oxygen glow-discharge, resulting in water contact angles of $140-150^{\circ}$ (untreated FEP-Teflon: $\left.109^{\circ}\right)$. Compared with untreated FEP-Teflon $\left(209 \mu \mathrm{m}^{2}\right.$ per cell), a significant decrease in the spreading of human skin fibroblasts was observed on superhydrophobic FEP-Teflon (158 $\mu^{2}$ per cell) (Figure 5). This work put in evidence that adhesion and spreading can be considered two different phenomena; in fact, while cell spreading on TCPS was significantly higher as compared with FEP-Teflon, the number of adhering cells on TCPS, however, was significantly higher than on the hydrophobic FEP-Teflon.
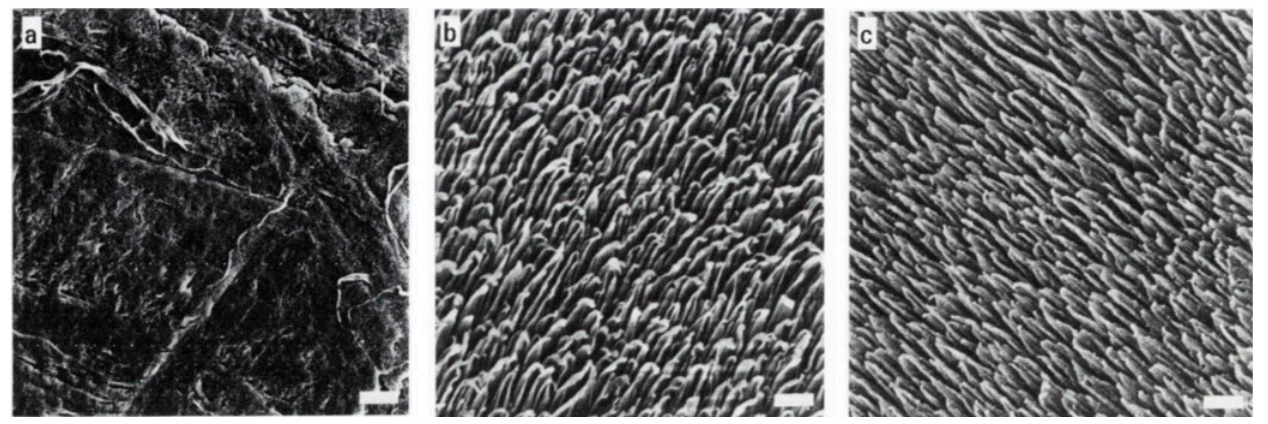

Figure 5. Light microscopy images of human skin fibroblasts attached to tissue culture-treated polystyrene (TCPS) (a), untreated FEP-Teflon (b), and hydrophobized FEP-Teflon (c). The bar denotes $37 \mu \mathrm{m}$. Reprinted from reference [93].

d. Cell proliferation on a patterned ordered structure obtained by plasma CVD and VUV irradiation as a combination of both highly hydrophobic and hydrophilic areas was investigated in the work of [94]. The correlation between chemistry, physicochemical properties of the surface, and adhesive behaviour of cells was investigated using such a surface as a scaffold for cell culture. The cell selectivity for superhydrophilic areas was confirmed by comparison with the superhydrophobic part finding the first roughness structure intact. In facts, the cells distributed regularly as circular arrays along the surface pattern with a distance negative effect over a certain size $(>400 \mu \mathrm{m})$ on the cell adhesive extension with the neighbours. Examining cell behaviour on superhydrophobic and superhydrophilic surfaces has demonstrated that cells adhered and proliferated on both surfaces; even on the superhydrophobic surface, they divide and proliferate in the presence of constant contact. In the study, the role of protein adsorption in the site selectivity in the final adhesion properties on different surfaces was underlined-far greater amounts of proteins adsorbed on the flat hydrophilic surface than on the flat hydrophobic surface.

e. Cell attachment is governed by differences in surface energy—higher energy hydrophilic surfaces promote adhesion, while low surface energy substrates usually inhibit cell adhesion. With the aim of providing control of cell adhesion, a combination of superhydrophobic with a specific high energy component like polydopamine was investigated [95]. Superhydrophobic surfaces with their extremely low surface energy can reduce cell adhesion, but in the presence of polydopamine, coatings can become a suitable substrate for cell adhesion. In other words, a selective polydopamine coating on a cell-repellent superhydrophobic background can improve the precision in cell proliferation control systems.

f. Nonfouling superhydrophobic silicon nanowire (SiNW) substrate in a stable Cassie-Baxter state, with limited contact with the culture medium, was investigated by exploiting the interface between nanowires and living cells for applications in fields like biomedical implants, biosensors, or drug delivery [96]. Vertically aligned SiNW arrays prepared by the stain etching technique were chemically modified with octadecyltrichlorosilane (OTS), resulting in a superhydrophobic SiNW surface with a contact angle around $160^{\circ}$. Then, by standard optical lithography techniques, a micropatterned superhydrophilic/superhydrophobic SiNW surface was created for a K1 Chinese 
hamster ovary $(\mathrm{CHO})$ cell culture investigation on patterned superhydrophilic/superhydrophobic silicon nanowire surfaces. As previously reported, superhydrophilic regions selectively discriminated cells' adhesion from superhydrophobic areas, where cell adhesion was almost completely inhibited. The penetration of cell cytoplasmic projections into the hydrophilic silicon nanowires layer, leading to a strong adhesion through an intimate surface contact, was evidenced by transmission electron microscopy. In contrast, the cell cytoplasmic projections remained on the top of wires in superhydrophobic regions.

g. The presence of trapped air in $\mathrm{TiO}_{2}$ nanotube microtemplated superhydrophobic/superhydrophilic surfaces plays a role in the formation of protein micropatterns, but not cells [97]. The superhydrophobic domains limit the adsorption of either bovine-serum albumin (BSA) or fetal-bovine serum (FBS) solutions, creating a strong contrast between superhydrophilic and superhydrophobic domains. It was observed that cell type and protein composition of the fluid phase influence micropatterns formation of cell (hFOB1.19, MG63, and HeLa), superhydrophilic domains are preferred by all cell types from each fluid phase (FBS, BSA, and basal media containing no protein). On the contrary, the attachment to superhydrophobic domains is not similar for all cell types: no attachment from FBS solutions, with-or-without trapped air, basal media suspensions promote cell attachment to superhydrophobic domains from, with-or-without trapped air, while mixed results are obtained from BSA-containing solutions (Figure 6). In fact, cell attachment seems to be controlled by interfacial tensions between cells, surfaces, and fluid phases. It was found that in the absence of trapped air, more proteins bind to superhydrophobic domains than to superhydrophilic ones [98]. In this case, the authors propose a system for creating patterns of multiple different cell types on one substrate. This method requires control of the spatial arrangement and geometry of different cell types, while keeping them separated and in close proximity for a long time in order to mimic and study a variety of biological processes in vitro. In comparison with existing patterning technologies limited to relatively simple geometry or, for the more complex, usually applicable to only one or two cell types, this approach can create pattern geometries of various complexity. Superhydrophobic borders built in a fine nanoporous polymer film confine the geometry of highly hydrophilic regions, allowing cell positioning in multiple cell-containing microreservoirs. As a case study, we showed the cross-talk between two cell populations via wingless-related integration site (Wnt) signaling molecules propagation during co-culture in a mutual culture medium.

h. With the aim of improving the correlation of in vitro and in vivo cellular functions, the requirements of mimicking natural tissue properties (such as chemistry, three-dimensional structure, mechanical properties, etc) in comparison with traditional polystyrene treated flat tissue cell culture dishes for growing, subculturing, and studying cell behavior are widely assessed [99]. Interestingly, NIH 3T3 fibroblasts showed significantly greater adhesion and proliferation on XanoMatrix cell culture dishes; this substrate can be considered a versatile growth platform with the mimicked nanoscale geometry of natural tissue fibers with true, tortuous fiber beds.

i. The physico-chemical characterization of an alternative platform surface affecting cells attachment and proliferation is proposed in a paper [100], in which wax-impregnated cotton fabrics were used as a microwell plate, easy to fabricate by a dipping and drying process. Microwell platforms are a widespread standard in cell-based assays and drug screening and, in this case, they represent a sustainable and environmentally friendly method. The influence of surface chemistry, hydrophobicity, and roughness was investigated on cultured human skin fibroblasts. The study underlines a potential use for future cell-based assay platforms, usually being made from non-biodegradable materials such as polystyrene or polyethylene or by the soft lithography and photolithography technique.

j. In a recent work, a study on the influence of coating polyester fabric at different degrees of hydrophobicity on a few mammalian cell viability lines was reported [101]. The composition 
and structure of the mixed organic-inorganic coating with moderate to high water repellence can be finely modulated, resulting in controlling the hydrophobicity of the fabric on commercial, low cost fabric substrates, providing advanced performance. Cell viability on TCPS surfaces with this superhydrophobic coating has efficiently decreased, independent of the cell line type. Comparing the ratio values with those observed on uncoated surfaces and a less hydrophobic coating, the $3 \mathrm{~T} 3$ or $\mathrm{HaCaT}$ cell line decreased their individual responses by 10 times the ratio values. In case of the HeLa line, the hydrophobic coating of polyester (PES) fabric was very efficient in minimizing viability in comparison with coating TCPS surfaces. From these results, tumor cell lines and non-tumor cell lines could be potentially discriminated based on their adhesion on PES fabrics.

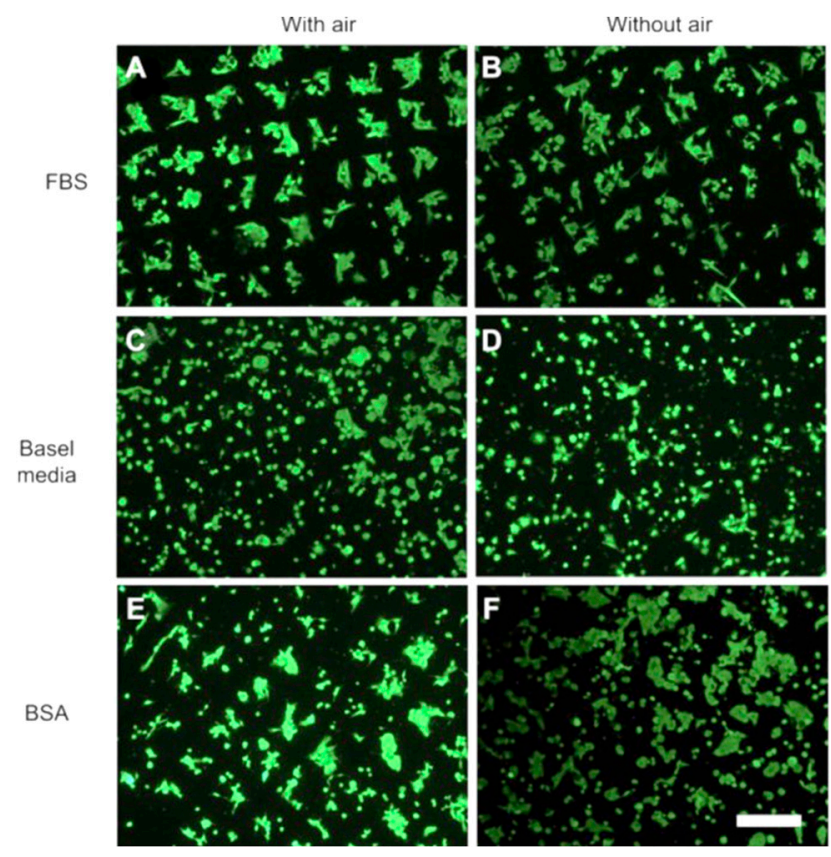

Figure 6. Scanning electron microscopy images of HeLa cells attached to superhydrophobic/ superhydrophilic microtemplates under different experimental conditions: cells cultured for one, two, and four days with (A,C,E) and without trapped air (B,D,F), respectively. Scale bar $\frac{1}{4} 200 \mathrm{~mm}$. Reprinted from reference [97] with permission from Elsevier.

\section{Conclusions}

In this work, the authors have reviewed the available literature outlining the role of surface properties involved in the hydrophobic or superhydrophobic state of a surface in relation to mammalian cell behaviour including cell adhesion, their communication, and proliferation. Despite that most of these properties are correctly treated independently in the literature, few of them can together significantly influence the substrate hydrophobicity, enhancing some aspects of biomedical applications like fabric durability or cell detachment. Among the examples, a strong dependence on the biochemical and biophysical features of the cell line and the loss of high water repellence in the case of long time exposure to liquids have to be evidenced. Nevertheless, the combination with different opposite properties like superhydrophilicity seems to open new perspectives in cell viability control.

Author Contributions: The manuscript was written through contributions of all authors. All authors have given approval to the final version of the manuscript. M.F. and M.C.M., conceptualization, writing-review \& editing, supervision, F.C. writing-review \& editing.

Funding: This research did not receive any specific grant from funding agencies in the public, commercial, or not-for-profit sectors. 
Acknowledgments: This work was conducted under the umbrella of Cooperation Agreement between Faculty of Pharmacy and Food Science (UB) and the Institute for Chemistry of Condensed Matter and Technologies for Energy (ICMATE-CNR) (Codi GREC 18407, 2018-2021). M.C. Morán and M. Ferrari acknowledge the support of UB-Mobility programme (OMPI-PR 1493, 2017-2018) for type A1 and type A2 grants, respectively. M. Ferrari acknowledges the support of Compagnia San Paolo through the ANFISOL Project.

Conflicts of Interest: The authors declare no conflict of interest.

\section{References}

1. Pierres, A.; Benoliel, A.M.; Bongrand, P. Cell-cell interaction. In Physical Chemistry of Biological Interfaces; Baszkin, A., Norde, W., Eds.; Marcel Dekker: New York, NY, USA, 1999; pp. 459-522.

2. Brochard-Wyart, F.; de Gennes, P.G. Adhesion induced by mobile binders: Dynamics. Proc. Natl. Acad. Sci. USA 2002, 99, 7854-7859. [CrossRef] [PubMed]

3. Lasky, L.A.; Singer, M.S.; Dowbenko, D.; Imai, Y.; Henzel, W.J.; Grimley, C.; Fennie, C.; Gillett, N.; Watson, S.R.; Rosent, S.D. An endothelial ligand for L-Selectin is a novel mucin-like molecule. Cell 1992, 69, 927-938. [CrossRef]

4. Szekanecz, Z.; Koch, A.E. Cell-cell interactions in synovitis: Endothelial cells and immune cell migration. Arthritis Res. 2000, 2, 368-373. [CrossRef] [PubMed]

5. Huang, S.; Ingber, D.E. The structural and mechanical complexity of cell-growth control. Nat. Cell Biol. 1999, 1, E131. [CrossRef] [PubMed]

6. Okegawa, T.; Pong, R.-C.; Li, Y.; Hsieh, J.-T. The role of cell adhesion molecule in cancer progression and its application in cancer therapy. Acta Biochim. Pol. 2004, 51, 445-457. [PubMed]

7. Hirohashi, S.; Kanai, Y. Cell adhesion system and human cancer morphogenesis. Cancer Sci. 2003, 94, 575-581. [CrossRef] [PubMed]

8. Perinpanayagam, H.; Zaharias, R.; Stanford, C.; Keller, J.; Schneider, G.; Brand, R. Early cell adhesion events differ between osteoporotic and non-osteoporotic osteoblasts. J. Orthop. Res. 2001, 19, 993-1000. [CrossRef]

9. Cho, P.; Schneider, G.B.; Kellogg, B.; Zaharias, R.; Keller, J.C. Effect of glucocorticoid-induced osteoporotic-like conditions on osteoblast cell attachment to implant surface microtopographies. Implant. Dent. 2006, 15, 377-385. [CrossRef]

10. Serhan, C.N.; Savill, J. Resolution of inflammation: The beginning programs the end. Nat. Immunol. 2005, 6, 1191-1197. [CrossRef]

11. Simon, S.; Green, C.E. Molecular mechanics and dynamics of leukocyte recruitment during inflammation. Annu. Rev. Biol. 2005, 7, 151-185. [CrossRef]

12. Spangenberg, C.; Lausch, E.U.; Trost, T.M.; Prawitt, D.; May, A.; Keppler, R.; Fees, S.A.; Reutzel, D.; Bell, C.; Schmitt, S.; et al. ERBB2-mediated transcriptional up-regulation of the $\alpha 5 \beta 1$ integrin fibronectin receptor promotes tumor cell survival under adverse conditions. Cancer Res. 2006, 66, 3715-3725. [CrossRef] [PubMed]

13. Zou, J.X.; Liu, Y.; Pasquale, E.B.; Ruoslahti, E. Activated Src oncogene phosphorylates R-ras and suppresses integrin activity. J. Biol. Chem. 2002, 277, 1824-1827. [CrossRef] [PubMed]

14. Mierke, C.T. Cancer cells regulate biomechanical properties of human microvascular endothelial cells. J. Biol. Chem. 2011, 286, 40025-40037. [CrossRef] [PubMed]

15. Schakenraad, J.M.; Busscher, H.J. Cell polymer interactions-the influence of protein adsorption. Colloids Surf. 1989, 42, 331-343. [CrossRef]

16. Harnett, E.M.; Alderman, J.; Wood, T. The surface energy of various biomaterials coated with adhesion molecules used in cell culture. Colloids Surf. B 2007, 55, 90-97. [CrossRef] [PubMed]

17. Nagase, K.; Kobayashi, J.; Okano, T. Temperature-responsive intelligent interfaces for biomolecular separation and cell sheet engineering. J. R Soc. Interf. 2009, 6, S293-S309. [CrossRef] [PubMed]

18. Vagaska, B.; Bacakova, L.; Filova, E.; Balik, K. Osteogenic cells on bio-inspired materials for bone tissue engineering. Physiol. Res. 2010, 59, 309-322. [PubMed]

19. Renner, L.D.; Weibel, D.B. Physicochemical regulation of biofilm formation. MRS Bull. 2011, 36, 347-355. [CrossRef] [PubMed]

20. Rosenfeldt, S.; Wittemann, A.; Ballauff, M.; Breininger, E.; Bolze, J.; Dingenouts, N. Interaction of proteins with spherical polyelectrolyte brushes in solution as studied by small-angle X-ray scattering. Phys. Rev. E 2004, 70, 061403. [CrossRef] [PubMed] 
21. Wittemann, A.; Haupt, B.; Ballauff, M. Adsorption of proteins on spherical polyelectrolyte brushes in aqueous solution. Phys. Chem Chem Phys. 2003, 5, 1671-1677. [CrossRef]

22. Worz, A.; Berchtold, B.; Moosmann, K.; Prucker, O.; Ruhe, J. Protein- resistant polymer surfaces. J. Mater. Chem. 2012, 22, 19547-19561. [CrossRef]

23. Ko, Y.G.; Kim, Y.H.; Park, K.D.; Lee, H.J.; Lee, W.K.; Park, H.D.; Kim, S.H.; Lee, G.S.; Ahn, D.J. Immobilization of poly(ethylene glycol) or its sulfonate onto polymer surfaces by ozone oxidation. Biomaterials 2001, 22, 21152123. [CrossRef]

24. Niepel, M.S.; Peschel, D.; Groth, T. Controlling fibroblast adhesion with $\mathrm{pH}$ modified polyelectrolyte multilayers. Int. J. Artif. Organs 2011, 34, 185-191. [CrossRef] [PubMed]

25. Zhang, M. Biocompatibility of materials. In Biomaterials and Tissue Engineering. Biological and Medical Physics, Biomedical Engineering; Shi, D., Ed.; Springer: Berlin/Heidelberg, Germany, 2004.

26. Ratner, B.D. The biocompatibility of implant materials. In Host Response to Biomaterials. The Impact of Host Response on Biomaterial Selection; BadylaK, S.F., Ed.; Academic Press: Cambridge, MA, USA, 2015.

27. Kulinets, I. Biomaterials and their applications in medicine. In Regulatory Affairs for Biomaterials and Medical Devices. A Volume in Woodhead Publishing Series in Biomaterials; Amato, S.F., Ezzell, R.M., Eds.; Woodhead Publishing: Cambridge, UK, 2015.

28. Oliveira, S.M.; Alves, N.A.; Mano, J.F. Cell interactions with superhydrophilic and superhydrophobic surfaces. J. Adhes. Sci. Technol. 2012, 28, 1-21. [CrossRef]

29. Ramires, P.A.; Mirenghi, L.; Romano, A.R.; Palumbo, F.; Nicolardi, G. Plasma-treated PET surfaces improve the biocompatibility of human endothelial cells. J. Biomed. Mater. Res. 2000, 51, 535-539. [CrossRef]

30. Pu, F.R.; Williams, R.L.; Markkula, T.K.; Hunt, J.A. Expression of leukocyte-endothelial cell adhesion molecules on monocyte adhesion to human endothelial cells on plasma treated PET and PTFE in vitro. Biomaterials 2002, 23, 4705-4718. [CrossRef]

31. Dowling, D.P.; Miller, I.S.; Ardhaoui, M.; Gallagher, W.M. Effect of surface wettability and topography on the adhesion of osteosarcoma cells on plasma-modified polystyrene. J. Biomater. Appl. 2011, 26, 327-347. [CrossRef] [PubMed]

32. Geckeler, K.E.; Wacker, R.; Martini, F.; Hack, A.; Aicher, W.K. Enhanced biocompatibility for SAOS-2 osteosarcoma cells by surface coating with hydrophobic epoxy resins. Cell. Physiol. Biochem. 2003, 13, 155-164. [CrossRef]

33. Vasita, R.; Shanmugam, K.; Katti, D.S. Improved biomaterials for tissue engineering applications: Surface modification of polymers. Curr. Top. Med. Chem. 2008, 8, 341-353.

34. Anselme, K.; Ploux, L.; Ponche, A. Cell/material interfaces: Influence of surface chemistry and surface topography on cell adhesion. J. Adhes. Sci. Technol. 2010, 24, 831-852. [CrossRef]

35. Lourenço, B.N.; Marchioli, G.; Song, W.; Reis, R.L.; van Blitterswijk, C.A.; Karperien, M.; van Apeldoorn, A.; Mano, J.F. Wettability influences cell behavior on superhydrophobic surfaces with different topographies. Biointerphases 2012, 7, 46.

36. Engler, A.J.; Sen, S.; Sweeney, H.L.; Discher, D.E. Matrix elasticity directs stem cell lineage specification. Cell 2006, 126, 677-689. [CrossRef] [PubMed]

37. Khatiwala, C.B.; Peyton, S.R.; Metzke, M.; Putnam, D. The regulation of osteogenesis by ECM rigidity in MC3T3-E1 cells requires MAPK activation. J. Cell Physiol. 2007, 211, 661-672. [CrossRef] [PubMed]

38. Chang, H.; Wang, Y. Cell responses to surface and architecture of tissue engineering scaffolds. In Regenerative Medicine and Tissue Engineering_Cells and Biomaterials; Eberli, D., Ed.; IntechOpen: London, UK, 2011.

39. Mason, B.N.; Califano, J.P.; Reinhart-King, C.A. Matrix stiffness: A regulator of cellular behavior and tissue formation. In Engineering Biomaterials for Regenerative Medicine; Bhatia, S., Ed.; Springer: New York, NY, USA, 2012.

40. Zemla, J.; Danilkiewicz, J.; Orzechowska, B.; Pabijan, J.; Seweryn, S.; Lekka, M. Atomic force microscopy as a tool for assessing the cellular elasticity and adhesiveness to identify cancer cells and tissues. Semin. Cell Dev. Biol. 2018, 73, 115-124. [CrossRef] [PubMed]

41. Szymon Prauzner-Bechcicki, S.; Joanna Raczkowska, J.; Madej, E.; Pabijan, J.; Lukes, J.; Sepitka, J.; Rysz, J.; Awsiuk, K.; Bernasik, A.; Budkowski, A.; et al. PDMS substrate stiffness affects the morphology and growth profiles of cancerous prostate and melanoma cells. J. Mech. Behav. Biomed. Mater. 2015, 41, 13-22. [CrossRef] [PubMed] 
42. Raczkowska, J.; Prauzner-Bechcicki, S.; Lukes, J.; Sepitka, J.; Bernasik, A.; Awsiuk, K.; Paluszkiewicz, C.; Pabijan, J.; Lekka, M.; Budkowski, A. Physico-chemical properties of PDMS surfaces suitable as substrates for cell cultures. Appl. Surf. Sci. 2016, 389, 247-254. [CrossRef]

43. Bartalena, G.; Loosli, Y.; Zambelli, T.; Snedeker, J.G. Biomaterial surface modifications can dominate cell-substrate mechanics: The impact of PDMS plasma treatment on a quantitative assay of cell stiffness. Soft Matter 2012, 8, 673-681. [CrossRef]

44. Fairhurst, D.; Rowell, R.L.; Monahan, I.M.; Key, S.; Stieh, D.; McNeil-Watson, F.; Morfesis, A.; Mitchnick, M.; Shattock, R.A. Microbicides forHIV/AIDS. 2. Electrophoretic fingerprinting of CD4+ T-cell model systems. Langmuir 2007, 23, 2680-2687. [CrossRef]

45. De Kerchove, A.J.; Elimelech, M. Impact of alginate conditioning film on deposition kinetics of motile and nonmotile Pseudomonas aeruginosa strains. Appl Environ. Microbiol. 2007, 73, 5227-5234. [CrossRef]

46. Burello, E. Profiling the biological activity of oxide nanomaterials with mechanistic models. Comput. Sci. Discov. 2013, 6, 014009. [CrossRef]

47. Czeslik, C.; Jackler, G.; Hazlett, T.; Gratton, E.; Steitz, R.; Wittemann, A.; Bal-lauff, M. Salt-induced protein resistance of polyelectrolyte brushes studied using fluorescence correlation spectroscopy and neutron reflectometry. Phys. Chem Chem Phys. 2004, 6, 5557-5563. [CrossRef]

48. Kim, S.E.E.A.; Kihm, K.D. Surface elasticity and charge concentration dependent endothelial cell attachment to copolymer polyelectrolyte hydrogel. Acta Biomater. 2009, 5, 144-151. [CrossRef] [PubMed]

49. Bet, M.R.; Goissis, G.; Vargas, S.; Selistre-de-Araujo, H.S. Cell adhesion and cytotoxicity studies over polyanionic collagen surfaces with variable negative charge and wettability. Biomaterials 2003, 24, 131-137. [CrossRef]

50. Schneider, G.B.; English, A.; Abahram, M.; Zaharias, R.; Stanford, C.; Keller, J. The effect of hydrogel charge density on cell attachment. Biomaterials 2004, 25, 3023-3028. [CrossRef] [PubMed]

51. Dadsetan, M.; Pumberger, M.; Casper, M.E.; Shogren, K.; Giuliani, M.; Ruesink, T.; Hefferan, T.E.; Currier, B.L.; Yaszemski, M.J. The effects of fixed electrical charge on chondrocyte behavior. Acta Biomater. 2011, 7, 2080-2090. [CrossRef] [PubMed]

52. Makohliso, S.A.; Valentini, R.F.; Aebischer, P. Magnitude and polarity of a fluoroethylene propylene electret substrate charge influences neurite outgrowth in vitro. J. Biomed. Mater. Res. 1983, 7, 1075-1085.

53. Lee, J.H.; Jung, H.W.; Kang, I.K.; Lee, H.B. Cell behaviour on polymer surfaces with different functional groups. Biomaterials 1994, 15, 705-711. [CrossRef]

54. Thevenot, P.; Hu, W.J.; Tang, L.P. Surface chemistry influences implant biocompatibility. Curr. Top. Medic. Chem. 2008, 8, 270-280.

55. Keselowsky, B.G.; Collard, D.M.; García, A.J. Integrin binding specificity regulates biomaterial surface chemistry effects on cell differentiation. Proc. Natl. Acad. Sci. USA 2005, 102, 5953-5957. [CrossRef]

56. Keselowsky, B.G.; Collard, D.M.; García, A.J. Surface chemistry modulates fibronectin conformation and directs integrin binding and specificity to control cell adhesion. J. Biomed. Mater. Res. A 2003, 66, 247-259. [CrossRef]

57. Guo, S.; Zhu, X.; Li, M.; Shi, L.; Ong, J.L.T.; Jańczewski, D.; Neoh, K.G. Parallel control over surface charge and wettability using polyelectrolyte architecture: Effect on protein adsorption and cell adhesion. ACS Appl. Mater. Interf. 2016, 8, 30552-30563. [CrossRef] [PubMed]

58. Gonçalves, S.; Dourado, F.; Rodrigues, L.R. Overview on Cell-Biomaterial Interactions. In Advanced Polymers in Medicine; Puoci, F., Ed.; Springer: Cham, Switzerland, 2015; pp. 91-128.

59. Donoso, M.G.; Méndez-Vilas, A.; Bruque, J.M.; González-Martin, M.L. On the relationship between common amplitude surface roughness parameters and surface area: Implications for the study of cell-material interactions. Int. Biodeter. Biodegr. 2007, 59, 245-251. [CrossRef]

60. Lee, S.J.; Choi, J.S.; Park, K.S.; Khang, G.; Lee, Y.M.; Lee, H.B. Response of MG63 osteoblast-like cells onto polycarbonate membrane surfaces with different micropore sizes. Biomaterials 2004, 25, 4699-4707. [CrossRef] [PubMed]

61. Bartolo, L.D.; Rende, M.; Morelli, G.G.; Salerno, S.; Piscioneri, A.; Gordano, A.; Di Vito, A.; Canonaco, M.; Drioli, E. Influence of membrane surface properties on the growth of neuronal cells isolated form hippocampus. J. Membr. Sci. 2008, 325, 139-149. [CrossRef]

62. Chung, T.W.; Liu, D.Z.; Wang, S.Y.; Wang, S.S. Enhancement of the growth of human endothelial cells by surface roughness at nanometer scale. Biomaterials 2003, 24, 4655-4661. [CrossRef] 
63. Kim, M.H.; Kino-Oka, M.; Kawase, M.; Yagi, K.; Taya, M. Response of human epithelial cells to culture surfaces with varied roughnesses prepared by immobilizing dendrimers with/without D-glucose display. J. Biosci. Bioeng. 2007, 103, 192-199. [CrossRef] [PubMed]

64. Dalby, M.J. Topographically induced direct cell mechanotransduction. Med. Eng. Phys. 2005, 27, 730-742. [CrossRef]

65. Washburn, N.R.; Yamada, K.M.; Simon, C.G., Jr.; Kennedy, S.B.; Amis, E.J. High throughput investigation of osteoblast response to polymer crystallinity: Influence of nanometer-scale roughness on proliferation. Biomaterials 2004, 25, 1215-1224. [CrossRef]

66. Ranella, A.; Barberoglou, M.; Bakogianni, S.; Fotakis, C.; Stratakis, E. Tuning cell adhesion by controlling the roughness and wettability of 3D micro/nano silicon structures. Acta Biomater. 2010, 6, 2711-2720. [CrossRef]

67. Zheng, J.; Song, W.; Huang, H.; Chen, H. Protein adsorption and cell adhesion on polyurethane/Pluronic surface with lotus leaf-like topography. Colloids Surf. B 2010, 77, 234-239. [CrossRef]

68. Boyan, B.D.; Hummert, T.W.; Dean, D.D.; Schwartz, Z. Role of material surfaces in regulating bone and cartilage cell response. Biomaterials 1996, 17, 137-146. [CrossRef]

69. Stevens, M.M.; George, J.H. Exploring and engineering the cell surface interface. Science 2005, 310, 1135-1138. [CrossRef] [PubMed]

70. Chen, H.; Yuan, L.; Song, W.; Wu, Z.; Li, D. Biocompatible polymer materials: Role of protein-surface interactions. Prog. Polym. Sci. 2008, 33, 1059-1087. [CrossRef]

71. Alves, N.M.; Pashkuleva, I.; Reis, R.L.; Mano, J.F. Controlling cell behavior through the design of polymer surfaces. Small 2010, 6, 2208-2220. [CrossRef] [PubMed]

72. Brown, X.Q.; Ookawa, K.; Wong, J.Y. Evaluation of polydimethylsiloxane scaffolds with physiologically-relevant elastic moduli: Interplay of substrate mechanics and surface chemistry effects on vascular smooth muscle cell response. Biomaterials 2005, 26, 3123-3129. [CrossRef] [PubMed]

73. Carré, A.; Mittal, K.L. Superhydrophobic Surfaces; VSP/Brill: Leiden, The Netherlands, 2009.

74. Young, T. An essay on the cohesion of fluids. Philos. Trans. R. Soc. Lond. 1805, 95, 65-87. [CrossRef]

75. Wenzel, R.N. Resistance of solid surfaces to wetting by water. Ind. Eng. Chem. 1936, 28, 988-994. [CrossRef]

76. Cassie, A.B.D.; Baxter, S. Wettability of porous surfaces. Trans. Faraday Soc. 1944, 40, 0546-0550. [CrossRef]

77. Bartolo, D.; Bouamrirene, F.; Verneuil, E.; Buguin, A.; Silberzan, P.; Moulinet, S. Bouncing or sticky droplets: Impalement transitions on superhydrophobic micropatterned surfaces. Europhys. Lett. 2006, 74, 299-305. [CrossRef]

78. Reyssat, M.; Pépin, A.; Marty, F.; Chen, Y.; Quéré, D. Bouncing transitions on microtextured materials. Europhys. Lett. 2006, 74, 306-312. [CrossRef]

79. Sbragaglia, M.; Peters, A.M.; Pirat, C.; Borkent, B.M.; Lammertink, R.G.H.; Wessling, M.; Lohse, D. Spontaneous breakdown of superhydrophobicity. Phys. Rev. Lett. 2007, 99, 156001. [CrossRef] [PubMed]

80. Sheng, X.; Zhang, J. Air layer on superhydrophobic surface underwater. Colloids Surf. A Physicochem. Eng. Asp. 2011, 377, 374-378. [CrossRef]

81. Mohammadi, R.; Wassink, J.; Amirfazli, A. Effect of surfactants on wetting of super-hydrophobic surfaces. Langmuir 2004, 20, 9657-9662. [CrossRef] [PubMed]

82. Ferrari, M.; Ravera, F.; Rao, S.; Liggieri, L. Surfactant adsorption at superhydrophobic surfaces. Appl. Phys. Lett. 2006, 89, 053104. [CrossRef]

83. Chang, F.M.; Sheng, Y.J.; Chen, H.; Tsao, H.K. From superhydrophobic to superhydrophilic surfaces tuned by surfactant solutions. Appl. Phys. Lett. 2007, 91, 094108. [CrossRef]

84. Extrand, C.W. Designing for optimum liquid repellency. Langmuir 2006, 22, 1711-1714. [CrossRef]

85. Gao, L.; McCarthy, T.J. A perfectly hydrophobic surface $\left(\theta \mathrm{A} / \mathrm{\Theta r}=180^{\circ} / 180^{\circ}\right)$. J. Am. Chem. Soc. 2006, 128, 9052-9053. [CrossRef]

86. Horbett, T.A. Protein adsorption on biomaterials. Biomater. Interf. Phenom. Appl. 1982, 199, 233-244.

87. Young, B.R.; Pitt, W.G.; Cooper, S.L. Protein adsorption on polymeric biomaterials: II. Adsorption kinetics. J. Colloid Interf. Sci. 1988, 124, 28-43. [CrossRef]

88. Ratner, B.D.; Hoffman, A.S. Nonfouling surfaces. Biomater. Sci. Introd. Mater. Med. 2004, 97-201.

89. Falde, E.J.; Yohe, S.T.; Colson, Y.L.; Grinstaff, M.W. Superhydrophobic materials for biomedical applications. Biomaterials 2016, 104, 87-103. [CrossRef] [PubMed]

90. Lih, E.; Oh, S.H.; Joung, Y.K.; Lee, J.H.; Han, D.K. Polymers for cell/tissue anti-adhesion. Prog. Polym. Sci. 2015, 44, 28-61. [CrossRef] 
91. Lee, J.N.; Jiang, X.; Ryan, D.; Whitesides, G.M. Compatibility of mammalian cells on surfaces of poly(dimethylsiloxane). Langmuir 2004, 20, 11684-11691. [CrossRef] [PubMed]

92. Yousefi, S.Z.; Tabatabaei-Panah, P.; Seyfi, J. Emphasizing the role of surface chemistry on hydrophobicity and cell adhesion behavior of polydimethylsiloxane/TiO2nanocomposite films. Colloids Surf. B Biointerfaces 2018, 167, 492-498. [CrossRef] [PubMed]

93. Busscher, H.J.; Stokroos, I.; Golverdingen, J.G.; Schakenraad, J.M. Adhesion and spreading of human fibroblasts on superhydrophobic Fep.Teflon. Cells Mater. 1991, 1, 243-249.

94. Ishizaki, T.; Saito, N.; Takai, O. Correlation of cell adhesive behaviors on superhydrophobic, superhydrophilic, and micropatterned superhydrophobic/superhydrophilic surfaces to their surface chemistry. Langmuir 2010, 26, 8147-8154. [CrossRef]

95. Kang, S.M.; Choi, I.S. Control of Cell Adhesion on a superhydrophobic surface by polydopamine coating. Bull. Korean Chem. Soc. 2013, 34, 2525-2527. [CrossRef]

96. Piret, G.; Galopin, E.; Coffinier, Y.; Boukherroub, R.; Legrand, D.; Slomianny, C. Culture of mammalian cells on patterned superhydrophilic/superhydrophobic silicon nanowire array. Soft Matter 2011, 7, 8642-8649. [CrossRef]

97. Huang, Q.; Lin, L.; Yang, Y.; Hu, R.; Vogler, E.A.; Lin, C. Role of trapped air in the formation of cell-and-protein micropatterns on superhydrophobic/superhydrophilic microtemplated surfaces. Biomaterials 2012, 33, 8213-8220. [CrossRef] [PubMed]

98. Efremov, A.N.; Stanganello, E.; Welle, A.; Scholpp, S.; Levkin, P.A. Micropatterned superhydrophobic structures for the simultaneous culture of multiple cell types and the study of cell-cell communication. Biomaterials 2013, 34, 1757-1763. [CrossRef] [PubMed]

99. Bhardwaj, G.; Webster, T.J. Increased NIH 3 T3 fibroblast functions on cell culture dishes which mimic the nanometer fibers of natural tissues. Int. J. Nanomed. 2015, 10, 5293-5299.

100. Wahab, N.M.; Jamil, S.A.; Riban, D.G.; Majid, F.A.A.; Kadir, M.R.A.; Wicaksono, D.H.B. Wax-Impregnated Cotton Fabrics as Cell Culture Platform. Adv. Mater. Res. 2015, 1112, 441-444. [CrossRef]

101. Morán, M.C.; Ruano, G.; Cirisano, F.; Ferrari, M. Mammalian cell viability on hydrophobic and superhydrophobic fabrics. Mater. Sci. Eng. C 2019, 99, 241-247. [CrossRef] [PubMed]

(C) 2019 by the authors. Licensee MDPI, Basel, Switzerland. This article is an open access article distributed under the terms and conditions of the Creative Commons Attribution (CC BY) license (http://creativecommons.org/licenses/by/4.0/). 